\title{
Achieving continuous project value in small hydropower plant projects by implementing Logical Framework Approach
}

Article history:

Received: 3 February 2020

Sent for revision: 5 February 2020

Received in revised form: 15 March 2020

Accepted: 16 March 2020

Available online: 31 March 2020

\begin{abstract}
Small hydropower plants (SHPPs) play an important role in European energy and infrastructure investment market. They contribute to green energy development and reduction of fossil fuel usage, but also interact with social and environmental wellbeing of the community. Logical Framework Approach with Logical Framework Matrix (LFA/LFM) is a project management tool developed by international financing institutions (IFIs) for the purpose of ensuring reliability and monitoring of complex multi-stakeholder projects and investments. Existing sustainability problems arising from SHPP projects throughout Europe are caused by underperforming development of SHPP projects. The goal of this paper is to show that usage of $L F A / L F M$ ensures sustainability and lasting project value throughout the project lifecycle in SHPP projects. Paper assesses key risks of developing and managing SHPP projects, tracing them back to the stakeholder assessment and project aim definition stages. Results of the paper show examples of SHPP projects in Serbia developed by using the LFA/LFM in some stages of its
\end{abstract}

1 Singidunum University, PhD student, miljan@radunovic.rs

2 Singidunum University, Assistant professor, gavlijas@singidunum.ac.rs 
project lifecycle, compared to the ones developed without using LFA/LFM in its project lifecycle. It then shows in what way LFA/LFM helps avoiding these risks in future development and management of SHPP projects. Finally, it advocates for extensive use of LFA/LFM by investors in future SHPP projects, by highlighting the key advantages of using LFA/LFM throughout the SHPP project lifecycle.

Keywords: Logical Framework Approach (LFA); small hydropower plants (SHPP), project value

\title{
Postizanje kontinuirane vrednosti projekta u projektima malih hidroelektrana kroz implementaciju Pristupa Logičkog Okvira
}

\begin{abstract}
Abstrakt: Male hidroelektrane (MHE) igraju važnu ulogu u evropskom tržištu energetike $i$ infrastrukturnih investicija. One doprinose razvoju zelene energije $i$ smanjenju korišćenja fosilnih goriva, ali takođe interaguju sa društvenim i okolnim blagostanjem društva. Pristup Logičkog Okvira sa Matricom Logičkog Okvira (PLO/MLO) je alat za projekt menadžment razvijen od strane međunarodnih finansijskih institucija (MFI) sa ciljem obezbeđivanja pouzdanosti $i$ nadzora kompleksnih projekata i investicija koje uključuju više učesnika. Postojeći problemi održivosti koji proizlaze iz MHE projekata širom Evrope su uzrokovani nedovoljno dobrom pripremom projekata MHE. Cilj ovog rada jeste da pokaže da korišćenje PLO/MLO obezbeđuje održivost i trajnu vrednost projekta tokom celog životnog ciklusa projekta MHE. Rad procenjuje ključne rizike razvoje i menadžmenta projekata MHE, vodeći nazad skroz do faza procene učesnika i definisanja cilja projekta. Rezultati rada pokazuju primere MHE projekata u Srbiji koji su razvijeni uz pomoć PLO/MLO u nekim fazama svog projektnog životnog ciklusa, poredeći ih sa onima koji su razvijeni bez korišćenja PLO/MLO u svom projektnom životnom ciklusu. Zatim se pokazuje na koji način PLO/MLO pomaže izbegavanju ovih rizika u budućem razvoju i menadžmentu MHE projekata. Konačno, on zagovara ekstenzivnu primenu PLO/MLO od strane investitora u buduće MHE projekate, naglašavajuči ključne prednosti korišćenja PLO/MLO tokom celog životnog ciklusa MHE projekta.
\end{abstract}


Ključne reči: Pristup Logičkog Okvira (PLO), male hidroelektrane (MHE), vrednost projekta

\section{Introduction}

Small hydropower plants (SHPPs) have played significant role in European renewable energy investment environment in the previous period. In existing and traditional environment, goal function of hydropower plants focuses on minimizing costs (George et al., 2010), while the structure of hydropower industry has changed significantly since the 1990s, with focus now being on private investments (Moore et al., 2010). In order to achieve initial financial sustainability and attract investors, SHPPs specifically require government financial stimulation in form of special feedin tariffs incentives (Meier et al., 2011), in order to ensure upfront capital investment.

In the recent period, development of SHPPs in European markets has faced a number of obstacles mainly linked to underperforming project preparation and development. This resulted in cost and schedule overruns of SHPP projects, overall inefficiency of the project management and failing to maintain the project value throughout the project lifecycle. Causes of the obstacles were traced back to insufficient assessments of stakeholders' interests in the project preparation phases. Given the present and future impact of SHPPs as renewable energy power generations sources in the European market, usage of reliable and proven project management tools is crucial for ensuring continuous project value and lasting sustainability of SHPP projects throughout their project lifecycle.

The goal of this paper is to show that using Logical Framework Approach with Logical Framework Matrix (LFA/LFM) in project development and management of SHPP projects ensures continuity of project value throughout the project lifecycle. LFA/LFM has proved to be a very useful tool in developing and managing projects, especially ones which account for a number of diverse stakeholders, have lengthy project lifecycle and complex funding structure. It outlines the key risk and pitfalls of existing SHPP projects in European market linking their origin to the planning and design phases. In the case of 89 analyzed SHPP units in Serbia, it is outlined that using LFA/LFM in project development phases of the SHPP projects ensures the continuity of project value throughout the project lifecycle, by keeping the number of problems in form of obstacles, complaints and project setbacks at minimum. The greatest leverage and competitive advantage of LFA/LFM as a project planning tools is its focus on assessing the interest of all stakeholders in the project prior to the construction phase of the SHPP project. 


\section{Literature review}

Modern business requires investors to be instigators of economic activity and bearers of progress, hence they are in constant search for ways to improve project development and project management of investments in this area. This is why the communication and cooperation between all stakeholders throughout the project lifecycle, needs to rest on mutual interest, transparent priorities and a methodology upon which those interests should be based (Jovanović \& Cvetković, 2018). In modern business, SHPP planning and construction is currently shifting from reputational strategy to business orientation. It is perceived as a way of living, doing and working in such a way that a company or any other third party improves the wellbeing and prevents the damaging of natural resources (Tinoco et al., 2016). Rethinking the value of a project, and what it presents to stakeholders has long been a subject of discussions. From one perspective, aforementioned value can be defined by benefits generated for stakeholders of the project, coming as a result of deploying project management (Oliomogbe \& Smith, 2013). Value of project management, however, has two streams: value from project outcome and value from deploying project management. Here internal stakeholders, namely owner and/or client, are concerned with the value of deployed project management, while external stakeholders are concerned with value from the project outcome (Zhai et al., 2009). Therefore, proper stakeholder assessment is of crucial importance in the early stages of project lifecycle.

Relevant literature offers a wide array of stakeholder categorizations. For example, Ruuska et al. (2009) define them as multiple firms, public organizations, authorities, political decision-making bodies and several owners while Zhai et al. (2009) see them as customers, community, subcontractors/suppliers and enterprises. This only proves that project management sustainability and value have a growing importance amongst academics and practitioners, and requires empirical evidence on how to achieve it in real life practice (Silvius et al., 2013).

Acknowledging that SHPPs can aid the market's transition from fossil fuels usage to more sustainable electrical energy production systems (Dursun \& Gokcol, 2011), the prevailing assumption that SHPPs are an inherently low impact technology is addressed by little systematic analysis or debate (Khurana \& Kumar, 2011). In theory, introduction of SHPPs was deemed as an overall win-win solution to a number of problems intersecting sustainable power generation, affordable energy 
supply, environment protection and technical innovations. However, frequency of problems arising from the implementation of SHPPs and the wide specter of these problems clearly indicate that there is still a lot to be done to ensure the efficient delivery of desired value throughout the complete lifecycle of a SHPP project. Table 1 shows the outputs of World Small Hydropower Development Report 2016 produced by United Nations Industrial Development Organization and International Center on Small Hydro Power, outlining the percentage of efficiency of installed SHPPs in European regions.

Table 1. Efficiency of SHPP potentials in regions of Europe

\begin{tabular}{|l|r|r|r|r|}
\hline SHPP efficiency & $43 \%$ & $39 \%$ & $39 \%$ & $85 \%$ \\
\hline Region of Europe & Eastern & Northern & Southern & Western \\
\hline Potential capacity [MW] & 4,470 & 10,919 & 16,310 & 7,243 \\
\hline Installed capacity [MW] & 1,924 & 4,281 & 6,286 & 6,183 \\
\hline
\end{tabular}

SHPP construction and operation interacts with its environment and affects its population in various ways and with different intensities. According to IPCC (2011) "affected population" term refers to project affected individuals living in the area impacted by hydropower project's preparation, implementation and/or operation. These may be within the catchment, reservoir area, downstream or in periphery where project associated activities occur, but also can include those living outside of the project-affected area who are economically affected by the project.

There is a growing number of international cases showing evidence that current rapid expansion of SHPP is associated with a range of negative impacts and increasing social conflicts. This shows that the negative impact of SHPP spans beyond water use, effecting a number of stakeholders at different scales and addressing multiple resources (Kelly-Richards et al., 2017). In Turkey, plans for development of SHPPs inspired disputes over forest, water and land acquisition, along with addressing environmental impact issues (Konak \& Sungu-Eryilmaz, 2016). Researchers in Norway concluded that social impact on activities such as hunting and recreation, as well as cumulative environmental impacts which harm wilderness areas, landscape aesthetics and endangered flora and fauna species, are more substantial per MW generated by SHPP than by large hydropower plant (Bakken et al., 2012). Council of Europe opened up a case-file against the Albanian government, urging them to immediately stop the constructions of Poçem and Kalivaç hydropower plants being built in Emerald protected sites, as they were 
identified as imminent danger to the ecosystem of Vjosa river, the last large wild river in Europe outside Russia.

Often SHPP project proposals can show a promising cost-benefit analysis with appealing investment assessment parameters such as net present value (NPV) and internal rate of return (IRR), but rely on data which concerns the surrounding market, environment or community, which is overoptimistic, unreal, unreliable, but also in some cases forged and incorrect. In the SHPP market of SEE, according to the World Small Hydropower Development Report 2016 produced by the UNIDO and the International Center on Small Hydro Power, SHPP investments face following obstacles which are mostly of stakeholder assessment nature:

- Bureaucratic and financial barriers

- Disagreements between local and national regulations, accompanied by frequent changes in SHP regulations

- High level of corruption

- Lack of master development plans for productive and sustainable SHPP sector

- Long and complicated authorization and licensing process

Logical framework Approach with Logical Framework Matrix (LFA/LFM), is a project planning tool developed by USAID in late 1970s. At that time, USAID was engaged in a number of international aid and support projects, and required a reliable and transparent tool for monitoring of its projects' development (Rosenberg, Posner \& Hanley, 1970). LFA/LFM proved to be very successful and spread to other international aid institutions similar to USAID. It is now widely used by institutions such as UNDP, World Bank, IFC and others.

European Commission (EC), through its mechanisms uses LFA/LFM extensively (Schmidt, 2009). In 2004 European Commission published its "Aid Delivery Methods - Project Cycle Management Guidelines - Supporting effective Implementation of EC External Assistance" document, in order to provide support to all project managers, companies, institutes and other interested stakeholders who wanted to engage in developing projects through EC funding mechanisms. This Project Cycle Management Guidelines (2004) document relied strongly on usage of LFA and production of LFM as its output document.

Today LFM is an integral component of project proposal documentation submitted in applications for projects funded by European Commission financial support mechanisms. It is included in the "Practical Guide on Contract Procedures for European Union External Action - PRAG", which provides contracting authorities, 
on one hand, and tenderers, candidates, applicants and contractors, on the other hand, with practical assistance in preparing and implementing procurement and grant contracts in field of external action.

As a project management tool, LFA/LFM presents a list of steps conducted prior to project commencing, execution and closing phases. The usage of LFA/LFM ensures minimum deviation from planned targets of the project and accounts for fulfillment of the desired interests of stakeholders and beneficiaries relevant to the project. There are two main phases in using the LFA/LFM as a project planning tool: Analysis Phase and Planning phase. The Analysis Phase focuses on the stakeholder, problem, objective, and strategy assessment of the project. In these steps, following key parameters of the project are defined, quantified and mutually interlinked:

- Stakeholders, their interests and capacities

- Key problems, their causes' and effects' relations, existing constraints and opportunities

- Assessment of identified problems and defining means to end cause and effect relationships

- Identifying different approaches and ways to achieve targeted solutions, as well as choosing the most suitable one according to measurable parameters

Figure 1. Logical Framework Matrix (LFM)

\begin{tabular}{|c|c|c|c|}
\hline $\begin{array}{l}\text { NARRATIVE } \\
\text { SUMMARY }\end{array}$ & $\begin{array}{l}\text { OBJECTIVELY } \\
\text { VERIFIABLE } \\
\text { INDICATORS }\end{array}$ & $\begin{array}{l}\text { MEANS OF } \\
\text { VERIFICATION }\end{array}$ & ASSUMPTIONS \\
\hline $\begin{array}{r}\text { Overall } \\
\text { objective }\end{array}$ & & & \\
\hline $\begin{array}{r}\text { Specific } \\
\text { objectives } \\
\end{array}$ & & & \\
\hline $\begin{array}{r}\text { Expected } \\
\text { results }\end{array}$ & & & \\
\hline \multicolumn{4}{|l|}{ Activities } \\
\hline & Means: & Costs: & \\
\hline
\end{tabular}


Planning Phase uses information and data collected and processed in Analysis Phase and places it in the Logical Framework Matrix (LFM) which is a four by four table, as presented in Figure1. LFM, as an output document, is of great importance as it is used and interpreted by different stakeholders in different stages of the project. Its precision and accountability ensure project sustainability throughout its lifecycle (Radunovic, 2018), which is especially important in projects with a lengthy lifecycles and complex pool of stakeholders, as is the case with the SHPP projects. LFM, as an output document, transiting throughout the project lifecycle, features three very efficient intervention logics - vertical, horizontal and cross-checked intervention logic. They are presented on Figure 2 in top right, bottom left and bottom right quadrant.

Figure 2. LFM and its three logical interventions

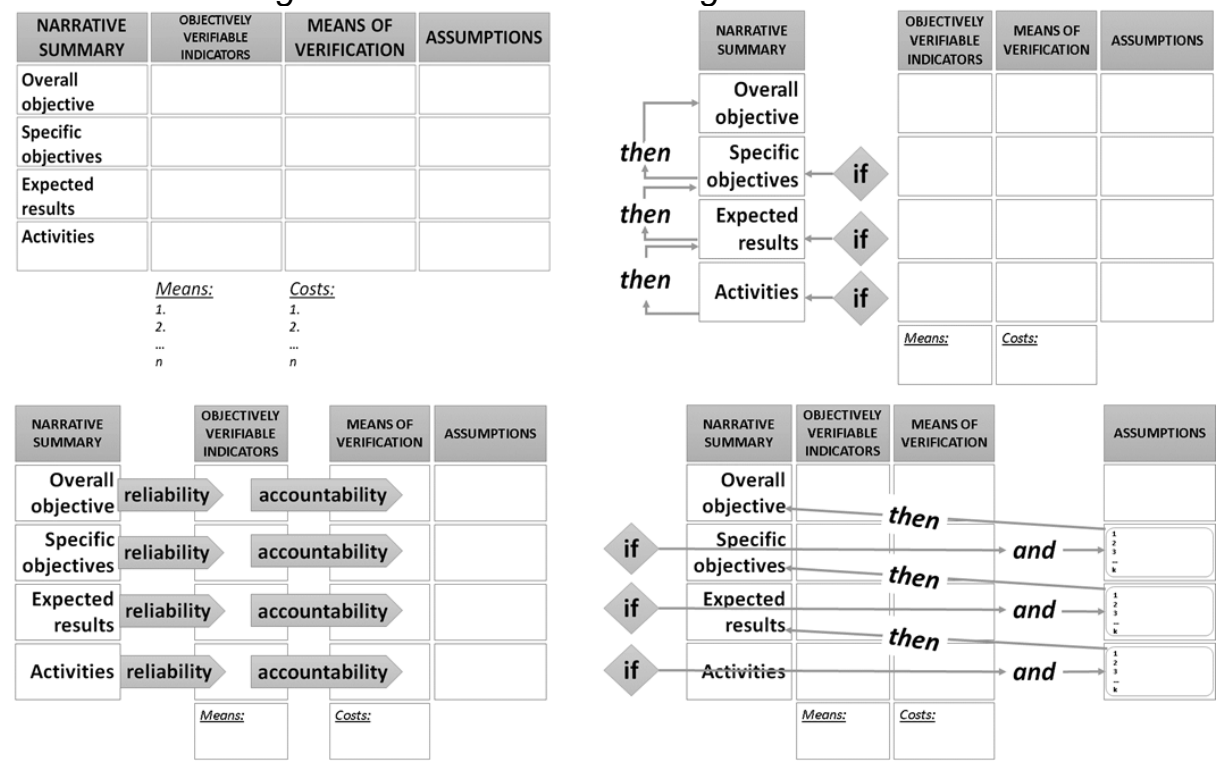

Vertical intervention logic, relies on the cause and effect relation within the vertical hierarchy of information collected and processed in LFA phases, constituting the structure of the project itself. This level of project structuring and assessment is most commonly present in all project proposal and investment documentation. 
Horizontal intervention logic provides additional assurance in the form of reliability and accountability for the likelihood of the proposed project. It provides a metric based assessment of the proposed - if used as a project development or management tool, or completed - if used as a monitoring tool for project activities which constitute the project. As such, it is valuable both for project managers for the purpose of tracking the project progress, as well as to the project sponsors for the purpose of proper monitoring and evaluation of conducted activities, for which the funding has been provided.

Finally, the cross-check intervention logic accounts for the risks, opportunities, and other external factors that can contribute to the project sustainability in both positive and negative way. As described in Figure 2, the cross-check intervention logic uses the "if - and - then" line of conclusion, with the following order:

1. if [Activity] and [Assumption(s)] then [Expected Result(s)] which is repeated on the next upper level, analogically as:

2. if [Expected Result(s)] and [Assumption(s)] then [Specific Objective(s)] and is accordingly followed by linking with the Overall Objective in the following way:

3. if [Specific Objective(s)] and [Assumption(s)] then [Overall Objective]

\section{Research materials and methodology}

Acknowledging the position that people use to determine the reality, and by accounting both individual and collective opinions and feelings of people and the community hosting SHPPs, the social constructionist approach has been adopted for the purpose of producing this paper. The goal of this approach is to increase the understanding of the situation by incorporating the stakeholder perspective into theories (Easterby-Smith et al., 2012). Methodology applied in this paper is based on the approach of building case studies, which is specifically useful for new research areas or research areas in which existing theory proves to be inadequate, so this makes it complementary to incremental theory building from normal science research (Eisenhardt, 1989).

Analysis scope limits - referring to optimum number of samples or cases to add and sufficient iteration between theory and data - is accounted for. As for optimal scope of analysis, adding research cases is completed once the theoretical saturation is reached. This comes as a result of the fact that theoretical saturation 
itself is the moment when incremental learning starts being minimal (Glaser,1967). Saturation also plays the key role in ending of iterations between theory and data. Once there is no incremental improvement in theory, or improvement is considered to be minimal, iterations are to stop and conclusion is drawn. End product of this process can be a novel concept - for example of deliberate and emergent strategies (Mintzberg, \& Waters, 1982), or an innovative conceptual framework for example on bankruptcy (Harris, \& Sutton, 1986), or a midrange theories or propositions - for example on politics in high velocity environments (Eisenhardt, \& Bourgeois III, 1988).

For the purpose of this paper, a total of 31 SHPP projects, all located in Serbia, accounting for 89 SHPP units, with total generation capacity of $62.88 \mathrm{MW}$, were analyzed. Data was collected from publicly available websites and databases of the Ministry of Mining and Energy of the Republic of Serbia, which is responsible for the policy regulation of SHPPs. The analyzed 89 SHPP units were installed in the period between 2010 and 2018.

\section{Results and discussion}

Fragmented, disconnected and complex structure of stakeholder relations in and around infrastructure projects, like SHPP ones, accompanied with rising interdependence between sectors, is reshaping the business models of infrastructure-based services, urging for the emergence of new approaches to governance and regulations (Hiteva et al., 2018). Articles and case studies focusing on identification of hydro potential useful for construction of SHPPs, suggest that, in developing markets, growth is oriented to new "high head" locations, found in mountainous regions (Al-Juboori \& Guven, 2016). However, in the mountainous areas, which host less or no infrastructural development, where the impact of SHPP construction, in specific through habitat fragmentation, it has even more impact than in river basins with existing infrastructure, like dams or roads (Bakken et al., 2012). These changes then provoke social impacts (Premalatha et al., 2014) which have a negative effect on SHPP project development and management. In Western Balkans market, and in this specific case in the Serbian market, financing of SHPP projects is mainly conducted in two ways:

- $\quad$ funding provided by international financing institutions (IFIs) via local commercial banking proxies; 
- private funding from companies or individuals.

These financing models differ in a number of ways and the differences affect the pace, sustainability and efficiency of the SHPP project itself. However, in cases of IFI financed SHPP projects, clear guidelines, policies and conditions are given and need to be followed throughout the project lifecycle on how to conduct the project initiation, development, design and execution. Most recent example of this is the Green Economy Financing Facility (GEFF) recently formed by European Bank for Reconstruction and Development (EBRD). The GEFF financing structure mechanism consists of participating financing partners and eligible borrowers. Financing partners act as proxy funding operators and communicate with eligible borrowers who act as third-party investors interested in developing projects such as SHPPs. According to rules of GEFF, eligible borrowers can be groups of individuals, housing associations, individuals, service providers and vendors. EBRD, as the head manager of GEFF, operates within the policy umbrella of the European Union (EU) and European Council (EC) as its executive body. EU and EC have long ago adopted and insist on the usage of Project Cycle Management (PCM) methodology of developing projects they are financing. The PCM approach was first introduced in 1992, when the EC initially published a PCM document which outlined a set of project design and management tools grounded in Logical Framework Approach with Logical Framework Matrix (LFA/LFM) which was by that time very frequently used in IFI community. In 2004 EC's European Aid Cooperation office updated the 1992 PCM document by publishing the "Aids Delivery Methods: Project Cycle Management Guidelines" document to support effective implementation of EC External Assistance. This document provided clear and concise guidelines on how to successfully develop and manage relevant, feasible and effective programs and projects that are to be supported by different structures of EC funding. The 2004 PCM Guidelines (page 144) introduced its views on what project, project lifecycle (there referred to as project cycle) and project management (there referred to as project cycle management) is:

- Project is a series of activities aimed at bringing about clearly specified objectives within a defined time-period and with a defined budget;

- Project cycle follows the life of a project from the initial idea through to its completion. It provides structure to ensure that stakeholders are consulted and defines the key decisions, information requirements and 
responsibilities at each phase so that informed decisions can be made at each phase in the life of a project;

- Project cycle management is a methodology for preparing, implementing and evaluating projects programs based on the principles of the Logical Framework Approach.

Table 2. Collected data on SHPP units in Serbia (built between $2010-$

\begin{tabular}{|l|l|c|c|}
\hline No & SHPP location & No. of SHPP units & Total installed power [kW] \\
\hline 1 & Aleksandrovac & 2 & 952 \\
\hline 2 & Aleksinac & 2 & 67.85 \\
\hline 3 & Babušica & 2 & 680 \\
\hline 4 & Bajina Bašta & 1 & 60 \\
\hline 5 & Bela Palanka & 3 & 1640 \\
\hline 6 & Bosilegrad & 2 & 1,015 \\
\hline 7 & Bujanovac & 1 & 250 \\
\hline 8 & Čačak & 2 & 11,500 \\
\hline 9 & Čajetina & 2 & 2,280 \\
\hline 10 & Crna Trava & 9 & 7,848 \\
\hline 11 & Despotovac & 2 & 3,000 \\
\hline 12 & Ivanjica & 3 & 1,888 \\
\hline 13 & Knjaževac & 5 & 1,313 \\
\hline 14 & Kraljevo & 6 & 6,316 \\
\hline 15 & Leskovac & 1 & 1,260 \\
\hline 16 & Ljubovija & 1 & 87 \\
\hline 17 & Mali Zvornik & 1 & 245 \\
\hline 18 & Nova Varoš & 3 & 2,410 \\
\hline 19 & Priboj & 2 & 1,838 \\
\hline 20 & Prijepolje & 5 & 1,682 \\
\hline 21 & Prokuplje & 1 & 160 \\
\hline 22 & Raška & 15 & 10,266 \\
\hline 23 & Sokobanja & 1 & 210 \\
\hline 24 & Surdulica & 1 & 230 \\
\hline 25 & Trgovište & 6 & 2,832 \\
\hline 26 & Tutin & 2 & 441 \\
\hline 27 & Užice & 2 & 262 \\
\hline 28 & Vladičin Han & 1 & 890 \\
\hline 29 & Vlasotince & 3 & 670 \\
\hline & & & \\
\hline
\end{tabular}




\begin{tabular}{|l|l|l|l|}
\hline 30 & Vranje & 1 & 180 \\
\hline 31 & Vranjska Banja & 1 & 350 \\
\hline
\end{tabular}

Table 2 shows the list of 31 SHPP projects, the constituting number of SHPP units, per project and total installed output for each of the SHPP project. Figure 2 shows the geographic locations of SHPP projects listed in Table 2.

Figure 3. Map of SHPP units in Serbia (built between 2010 - 2018)

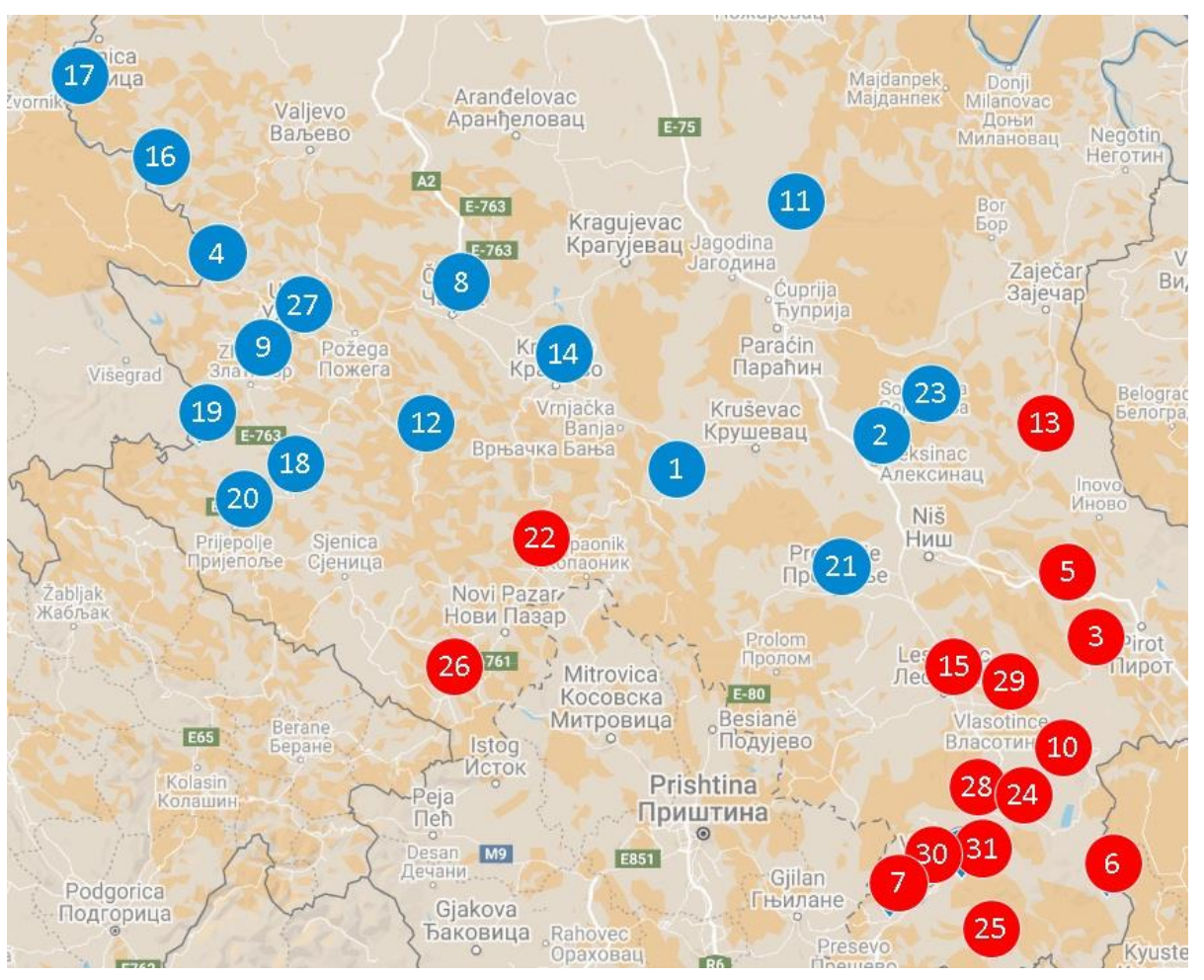

In Figure 3, SHPP project locations marked with blue circles are the ones which were predominantly financed by IFI support funding (such as EBRD), whereas the ones marked in red circles were the ones funded by private investors. The IFI 
funded ones showed little or no deviations of the project value, throughout the project lifecycle. On the other hand, a number of problems occurred in SHPP projects that were developed by individuals or private companies. These, privately funded, SHPP projects were funded with no requirements of aligning their project development and project management methodology with PCM nor any other to that matter.

Analysis showed that projects which did not fully abide to the IFI recommended project development and management methodology, in this case PCM which relies on LFA/LFM, encountered severe obstacles in the construction phase, caused by discontent, protests, obstruction and intervention of various stakeholders representing the local community and environmental activists. In these cases, issues were raised on justifiability and appropriateness of the SHPP project in the specific location, quality of preparation and development phase documents design - with special emphasis on documents assessing the environment protection issues and the impact of SHPPs on the local natural habitat. The effect of the problems led by local activists and stakeholders in form of nongovernmental organizations caused severe setbacks, public disputes leading to riots, project delays and ultimately additional expenses to investors of SHPP projects. In these cases, not accounting for interests of stakeholders in the initial phases of the SHPP project was the cause of problems that occurred in the later stages, at which point there was no or minimum space for redesigning the already adopted technical solution which was to be implemented.

As a form of a warning, in fall 2018 the Energy Community (EnC), issued a statement as a reaction to reports of a number of SHPP projects being implemented in the southeastern European region directly jeopardizing environment, facing severe protests from local communities and disregarding the rule of law applicable in this area, all for the purpose of supporting SHPP investors' interests. European Parliament adopted a number of resolutions clearly instructing EBRD and European Investment Bank (EIB), as leading IFI lenders for construction of SHPPs to reconsider approvals of further investments in SHPP projects in this region and conduct detailed cross-sector assessment of submitted projects proposals. Resolutions on Macedonia, Montenegro and Serbia, suggested EBRD and EIB to take actions such as "withdrawal of funding for all projects being undertaken in protected areas", since some project reviews have showed such projects to "lack 
sound ex ante environmental impact assessments and strategic environmental assessment".

In the effects of construction and operation of SHPP, reliable and measurable parameters for analysis can be traced back in order to assess its justifiability and feasibility, in the planning and development phases of the SHPP project. Only once these effects are properly assessed upfront, the justifiability and profitability of constructing a SHPP according to the proposed design can be successfully concluded. In case SHPP construction and operation results in negative effects for local community, these effects too are measurable. They can be quantifiable in terms of costs of the rehabilitation of reconstruction of the surroundings, hence these costs can be compared to the profit and overall benefits provided by the SHPP. This makes it possible to conclude whether the proposed design of SHPP is justifiable and profitable.

Stakeholder assessment is systematically conducted in LFA process and it accounts for detecting, defining and prioritizing all stakeholders that directly or indirectly relate to the accomplishment of the project. Similar tools, such as Stakeholder Matrix can be used in this step of LFA in order to clarify the role, responsibility, influence and interest of all parties involved in the project, regardless of the importance of their role or moment in the project lifecycle in which they contribute to the project. This way, situations in which a problem occurs can be avoided once construction phase commences, or once SHPP starts operations, at which point it is impossible for the project to be altered or redefined in a way which allows to undo the occurred problem. Assumptions assessment phase is also very important step in the LFA, and accordingly in LFM (Figure 3) as output document. It translates all of the data collected, processed and filtered so that it is available to all stakeholders contributing to the project development, throughout the whole project lifecycle. The most important aspect of detecting, collecting and processing assumptions is their feature of being measurable.

Systematic and metric based assessment of stakeholders in the development phase is one the key leverages of LFA/LFM as a project development tool. As such, it can be used in developing SHPP projects, and can bring concrete and measurable business benefits both to investors and other relevant stakeholders. In addition to this, accounting for policy and regulation issues as business environment features, hydropower plant owners can expect an increase of profits by bidding on several markets at the same time, as a result of near deterministic environment such as day-ahead markets (Krajcar et al., 2017). As an output document of LFA, the LFM introduces the Objectively Verifiable Indicators (OVI) 
and Means of Verification (MOV) as parameters that link the key input and input information crucial for the sustainability of the project. By incorporating them in the LFM, which transits throughout the project lifecycle and interacts with all stakeholders relevant to the project's sustainability, it ensures minimum deviation from the initial planning and maximum delivery of project value.

\section{Conclusion}

SHPP projects in modern European market are facing constant problems which have their origins in the project preparation phase. Not accounting for all relevant stakeholders' interests in the initial phases of the SHPP projects, causes obstacles in the execution phases of the projects, which can't be undone or fixed at that time, and cause schedule and budget crashes of SHPP projects. LFA/LFM ensures important structure and methodology to account for surroundings' and stakeholders' anticipation and assessment of direct and indirect risks that can affect the project of SHPP development, construction and operation. The transition points in the project lifecycle, in which information is handed over from one level of authority to another, carry the greatest risk for project failure, and require strict metric-based project management and monitoring tools in order to ensure project sustainability, minimum deviation from initial plans and maximum fulfillment of all stakeholders' interest. LFA/LFM was initially made with the intention of monitoring the performance of project development and management in cases when the financing side is not directly involved in the execution of the project. Streamlining the data and information flow throughout the project lifecycle, ensures minimum deviation when comparing what was planned to what has been accomplished, enables maximum delivery of desired project value through the project lifecycle, thus making the project itself sustainable. For doing this in the most precise way, usage of common project management tools in all phases of the project lifecycle is crucial. LFA/LFM has so far proven itself to be a tool that ensures minimum risk of information deforming throughout the project lifecycle. This ultimately leads to sufficient and satisfactory level of project and investment sustainability.

Advocating the usage of LFA/LFM throughout the project lifecycle of a SHPP investment finds reasonable and firm grounds in the fact that LFA/LFM originates from the environment that currently promotes and conducts investments in SHPPs, and similar renewable energy facilities, as its highest priority - the IFIs themselves. Looking at it from one end of the project lifecycle -the IFI providing the funding LFA/LFM has established itself to be a reliable, accountable and trustworthy project management tool. Looking at it from the opposite direction - private investors 
interested in investing in SHPPs - LFA/LFM can be the most efficient and effective tool enabling them to achieve the targeted business goals, successfully aligning their interests with interests of the IFI providing the investment, while at the same time, ensuring that project development, execution and later operation do not cause any damage or harm to the environment.

\section{REFERENCES}

Al-Juboori, A. M., \& Guven, A. (2016). Hydropower plant site assessment by integrated hydrological modeling, gene expression programming and visual basic programming. Water resources management, 30(7), 2517-2530. doi: 10.1007/s11269-016-1300-3

Bakken, T. H., Sundt, H., Ruud, A., \& Harby, A. (2012). Development of small versus large hydropower in Norway-comparison of environmental impacts. Energy Procedia, 20, 185-199. doi: 10.1016/j.egypro.2012.03.019

Bakken, T. H., Sundt, H., Ruud, A., \& Harby, A. (2012). Development of small versus large hydropower in Norway-comparison of environmental impacts. Energy Procedia, 20, 185-199. doi: 10.1016/j.egypro.2012.03.019

Dursun, B., \& Gokcol, C. (2011). The role of hydroelectric power and contribution of small hydropower plants for sustainable development in Turkey. Renewable Energy, 36(4), 1227-1235. doi: 10.1016/j.renene.2010.10.001

Easterby-Smith, M., Thorpe, R., \& Jackson, P. R. (2012). Management research. Sage.

Eisenhardt, K. M. (1989). Building theories from case study research. Academy of management review, 14(4), 532-550. Retrieved from: https://pdfs.semanticscholar.org/ad19/b994ed568156c5e9ca8763e8013bc5 d1e0c6.pdf

Eisenhardt, K. M., \& Bourgeois III, L. J. (1988). Politics of strategic decision making in high-velocity environments: Toward a midrange theory. Academy of management journal, 31(4), 737-770. doi: 10.5465/256337

George, A., Reddy, M. C., \& Sivaramakrishnan, A. Y. (2010). Short term hydro thermal scheduling based on multi-objective genetic algorithm. International Journal of Electrical Engineering, 3(1), 13-26. Retrieved from: http://www.semanticscholar.org/paper/Short-Term-Hydrothermal-

Scheduling-based-on-Genetic-GeorgeReddy/acd83fe3553b602007baec2b6c02cd332e0195a4

Glaser, B., \& Strauss, A. (1967). The discovery of grounded theory. 1967. Weidenfield \& Nicolson, London, 1-19. Retrieved from: http://www.sxf.uevora.pt/wp-content/uploads/2013/03/Glaser_1967.pdf 
Harris, S. G., \& Sutton, R. I. (1986). Functions of parting ceremonies in dying organizations. Academy of Management journal, 29(1), 5-30. doi: $10.5465 / 255857$

Hiteva, R., Lovell, K., McArthur, J. M., Smith, H., \& Zerjav, V. (2018). Emerging approaches and issues in regulation and governance of infrastructure based services. doi: 10.14324/000.wp.10060167

Ilak, P., Rajšl, I., Herenčić, L., Zmijarević, Z., \& Krajcar, S. (2018). Decentralized electricity trading in the microgrid: Implementation of decentralized peer-topeer concept for electricity trading (P2PCET). doi: 10.1049/cp.2018.1868

Jovanović, D., \& Cvetković, D. (2018). Multiple Decision Making Criteria in the Implementation of Renewable Energy Sources. Tehnički vjesnik, 25(5), 1492-1496. doi: 10.17559/TV-20161225153248

Kelly-Richards, S., Silber-Coats, N., Crootof, A., Tecklin, D., \& Bauer, C. (2017). Governing the transition to renewable energy: A review of impacts and policy issues in the small hydropower boom. Energy Policy, 101, 251-264. doi: 10.1016/j.enpol.2016.11.035

Khurana, S., \& Kumar, A. (2011). Small hydro power-A review. International Journal of Thermal Technologies, 1(1), 107-110. Retrieved from: https://www.yumpu.com/en/document/view/28095182/small-hydro-power-areview-inpressco

Konak, N., \& Sungu-Eryilmaz, Y. (2016). Does Small Run-of-River Hydro Power Development in Turkey Deliver On Its Sustainability Premise?. Society \& Natural Resources, 29(7), 807-821. doi: 10.1080/08941920.2015.1086459

Meier, P., Zolezzi, E. H., Bogach, S. V., Muir, T., \& Bazex, K. (2011). Peru Opportunities and Challenges of Small Hydropower Development. Retrieved from: https://openknowledge.worldbank.org/bitstream/handle/10986/17500/63668 OWP0Peru000Box0361524B0PUBLIC0.pdf

Mintzberg, H., \& Waters, J. A. (1982). Tracking strategy in an entrepreneurial firm. Academy of management journal, 25(3), 465-499. doi: 10.5465/256075

Moore, D., Dore, J., \& Gyawali, D. (2010). The World Commission on Dams+ 10: Revisiting the large dam controversy. Water Alternatives, 3(2). Retrieved from: http://www.water-alternatives.org/index.php/allabs/79-a3-2-2/file

Oliomogbe, G. O., \& Smith, N. J. (2013). Does the deployment of project management itself provide benefits? Both tangible and intangible. In Proceedings 29th Annual Association of Researchers in Construction Management Conference (pp. 881-891). Association of Researchers in Construction Management. Retrieved from: http://www.arcom.ac.uk/docs/proceedings/ar2013-0881-0891_Oliomogbe_Smith.pdf 
Premalatha, M., Abbasi, T., \& Abbasi, S. A. (2014). A critical view on the ecofriendliness of small hydroelectric installations. Science of the Total Environment, 481, 638-643. doi: 10.1016/j.scitotenv.2013.11.047

Radunović, M. (2018). Controlling Obor Projects' Risks by Applying Modern Project Management Tools. FINIZ 2018-The Role of Financial and NonFinancial Reporting in Responsible Business Operation, 37-45. doi: 10.15308/finiz-2018-37-45

Rosenberg, L. J., Posner, L. D., \& Hanley, E. J. (1970). Project evaluation and the project appraisal reporting system. USA: Agency for international development. Fry consultants incorporated.

Ruuska, I., Artto, K., Aaltonen, K., \& Lehtonen, P. (2009). Dimensions of distance in a project network: Exploring Olkiluoto 3 nuclear power plant project. International Journal of Project Management, 27(2), 142-153. doi: 10.1016/j.ijproman.2008.09.003

Schmidt, T. (2009). Strategic project management made simple: Practical tools for leaders and teams. John Wiley \& Sons.

Silviusab, A. G., Schipperb, R., \& Nedeskia, S. (2013). Sustainability in project management: Reality bites1. Retrieved from: https://pmworldlibrary.net/wpcontent/uploads/2013/03/pmwj7-feb2013-schipper-nedeski-silviussustainability-pm-reality-biles-second-edition.pdf

Tinoco, R. A., Sato, C. E. Y., \& Hasan, R. (2016). Responsible project management: Beyond the triple constraints. Journal of Modern Project Management, 4(1), 81-93. Retrieved from: http://sro.sussex.ac.uk/id/eprint/65808/

Zhai, L., Xin, Y., \& Cheng, C. (2009). Understanding the value of project management from a stakeholder's perspective: Case study of mega-project management. Project Management Journal, 40(1), 99-109. doi: 10.1002/pmj.20099 